\title{
Sources for Reconstructing Ancient Forms of Śiva Worship*
}

\author{
Śiva Caturmukha
}

\section{The myth of Tilottama}

In chapter 203 of the Ádiparvan of the Mahābhārata we are told that, in order to kill the Asuras Sunda and Upasunda, who could only be killed by each other, Viśvakarman, ordered by Brahmā, creates a woman of unparallelled beauty. The Grandfather tells her to go to the two demons and to seduce them in order that they may kill one and other in their rivalry over her. This beauty, named Tilottamā, promises to do so and takes her leave of the gods by making a circumambulation. Among those gods is Bhagavat Maheśvara, who sits to the south (scil. of Brahmā) with his face turned east, whereas the gods sit to the north (of him) and the rstis all around (see below Textual Sources No. 2 (TS 2) v. 21). Only Indra and Bhagavat Sthāṇu (i.e. Maheśvara) are able to preserve their composure, but the latter's excessive desire to watch her (drasțtukāmasya cātyartham) leads to the coming forth of three more faces (mukha), one directed towards the south, which is possessed of curling lashes (añcitapaksmantam), one to the west and one to the north, the latter two not further qualified (TS 2 vv.22-24). In this way Sthānu Mahādeva became four-faced (caturmukhah). Indra, on the other hand, issues forth eyes on all sides up to a thousand (TS 2 vv. 25-26).

The curling eyelashes apart, the myth in this form does not yet refer to different aspects of Śiva that are represented by these faces, but his qualification of 'Post' (sthānu) may hint at his ithyphallic nature. That the appellation 'Sthānu' may have a phallic connotation emerges from the ambiguous and rather obscure nirukti in MBh 7.173.92 (TS 5 v.92): 'Because he burns (/destroys) when standing erect, and, because his standing (erect) is the arising of the vital breath, and, because his phallus is always standing, therefore is he known as "Post"."1

The myth of Tilottamā is taken up in the Anuśāsanaparvan, where significant iconographic features are added. An allusion to his ithyphallic nature

\footnotetext{
* The first version of this article was published in Grimal, François (ed.), Les sources et le temps/Sources and Time. A colloquium. Institut français de Pondichéry, EFEO, Pondichéry 2001. pp. 397-412. Publications du département d'indologie 91.

1 The same verse with variant readings is found in MBh 13.146.10.
} 
is absent here. Instead it is explained how Śiva assumed a quadruple form (caturmūrtitva), which may not be exactly equivalent to 'a form with four heads' (TS 7 vv. $3-6$ ).

Wherever she with beautiful teeth (i.e. Tilottamā) came into my vicinity, there, O Goddess, emerged a lovely head of mine. Wishing to watch her, I assumed a quadruple form with the help of yoga. Having become four-faced, while showing my own yoga, I exercise sovereignty (indratva) with my eastern face, with my northern one I sport ( ramāmi) with you, O blameless one (Umā); my western face is gentle (saumya) and conveys happiness to all living beings; my southern face, which has a terrifying appearance and is fierce ( raudra), destroys the creatures.

Translating this description into iconography, we may tentatively infer that the main head, which faces east, has the stern countenance of the yogin, that the southern face expresses the ferocious (ugra) aspect, that the northern face expresses delight $(\sqrt{ }$ ram $)$, whereas the western benevolent (saumya) face, which bestows happiness to the world, may have, by virtue of this function, a regal appearance, which may be symbolized by the turban (usñ $s a)$, although the text does not explicitly specify this headgear. The Mahābhārata text seems to assign these four aspects - asceticism (yogin), ferociousness (ugra/raudra), benevolence (saumya) towards the world (i.e. uṣnișin), and delight - to an anthropomorphic form of Śiva Maheśvara, who describes himself further as possessed of matted hair (jatila), celibate (brahmacārin), with the Pināka bow in his hand, and with a lustrous throat, śrikantha (TS 7 vv.7-8). It is this quartet of aspects that seems to underly, admittedly with some variations, the early sculptural representations of Śiva, no matter whether we are concerned with a caturmukhalinga (aniconic) or with an anthropomorphic image. This may be illustrated by some early examples.

\section{Images of Siva in his quadruple form}

In the statue found in Bhita, datable around the beginning of the Common Era, ${ }^{2}$ Śiva's main characteristic, viz. his ascetic, i.e. yogin nature, is represented by the central anthropomorphic figure, who is provided with matted locks (jatila) and penis erectus (Plate 109). Unlike his description in the Mahābhārata quoted above this central figure does not carry the bow Pināka, but rather seems to conform to devotional demands in that he carries the vessel (kalaśa) of amrta in his left hand, while the right hand seems to be raised in abhayamudrā. ${ }^{\dot{3}}$

This main deity is further characterized by four distinctive aspects symbolized by a 'girdle' of four heads around his waist, only partly in conformity with the Mahābhārata description. One of the heads clearly represents

2 Kreisel 1986, 54 f.; Abb. A 1a-f; State Museum Lucknow H 4.

3 Kreisel 1986, 57. Cf. the Śiva image found in Rishikesh: Kreisel 1986, 89 f. Abb. 70; Srinivasan 1997, 223, Pl. 17.10; Bakker 2014, 181 Plate 19. 
his ferocious aspect (ugra) and may therefore be directed towards the south, which would entail that the main central figure is facing southwest. ${ }^{4}$ The head to the left of the ugra facei.e. the one directed towards the east, if the main image faces southwest - is described by Kreisel in Die Śiva-Bildwerke der Mathurā-Kunst as follows.

Als einziger der Häupter ist er ohne Ohrund Halsschmuck dargestellt. Der Haaransatz ist nur als leichte Aufwölbung erkennbar, das offenbar kurzgeschorene Haar liegt ohne Zeichnung glatt am Schädel-sofern nicht ein Kahlkopf (munda) gemeint ist. Die schmucklose Darstellung läßt auf den asketischen Charakter dieses Kopfes schließen, allerdings in einem anderen Sinne als beim ekstatischen Yogin. ${ }^{5}$

The 'ecstatic yogin' differs from the 'ascetic' one, according to Kreisel; with the latter 'scheint der gelehrte brahmanische Asket, wahrscheinlich der-nicht notwendig jugendliche - keusche Brahmacārin oder Saṃnyāsin gemeint zu sein' (ibid.). Kreisel and others consequently arrive at a fivefold scheme, which is supposed to underly the Bhita sculpture.

However, the differentiation of the yogin into two forms within the context of a spa-

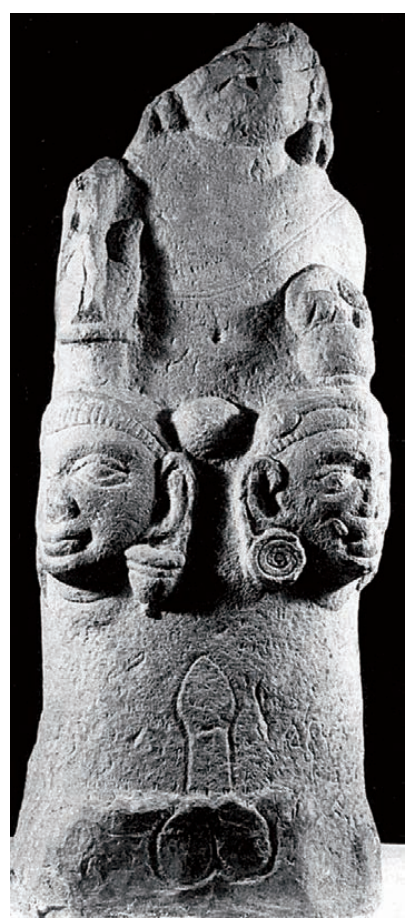

Plate 109

Image found in Bhita tial ramification fails in the Mahābhārata description and in any other early text and it may hence be doubtful whether a fivefold scheme really informed the early sculptures. The image seems rather to express the idea of one central deity not counted as an aspect, a deity who is possessed of or shaped by four aspects, the ones specified in the Mahābhārata, of which the yogin aspect in the present image is symbolized by the head of the samnyāsin/mundin, which is facing east in case of a southwestern orientation of the main deity. ${ }^{6}$

4 If the main figure faces east, the ugra head would face northeast, which is not plausible See below, p. 507.

5 Kreisel 1986, 58.

6 This orientation of the Bhita sculpture is based on the assumption that the ugra head faces south. Kreisel op. cit. $60 \mathrm{f}$. takes as the most likely direction of the main figure the south, which entails that the four heads are facing the intermediate quarters. Kreisel explains this unusual orientation by the hypothesis, earlier proposed by J.N. Banerjea 1935, $36 \mathrm{ff}$., that the Bhita sculpture represents an ancestor monument (Kreisel 1986, 55, 60). This assumption would not be contradicted, but rather reinforced, by an orientation 
The aspects represented by the remaining two heads of the Bhita sculpture, described by Kreisel as saumya and uṣnșin, agree with the two other aspects assigned to Maheśvara in the quoted Mahābhārata passage, if we are allowed to equate the face qualified as saumya by Kreisel with the one that in the Mahābhārata is said to sport with Umā (ramāmi). The relation to the quarters remains problematic however; evidently the orientation of the uṣnssin and saumya faces were not yet fixed. On the basis of the text one would expect that the head with which he sports with Umā (said to face north), is placed opposite of the ugra face (said to face south), which position in the Bhita sculpture, however, is occupied by the turbaned head, which, according to our interpretation of the Mahābhārata text, should face west. An uṣnısṣin head in the western quarter is indeed found in an early caturmukhalinga to which we turn now.

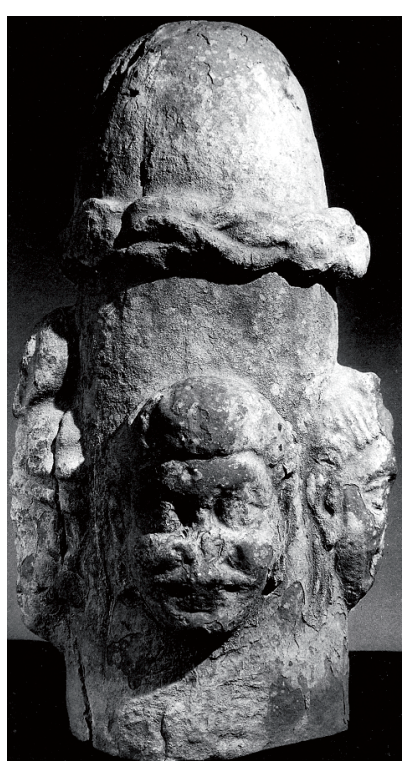

Plate 110

Mathurā: Caturmukhalinga

The probably oldest Caturmukhalinga that has been found is the Mathurā linga preserved in the National Museum Delhi (NM 65.172), which according to Kreisel is datable to about AD 100 (Plate 110). ${ }^{7}$ Its faces in eastern, southern and western directions conform to the Mahābhārata description in that they express Śiva's yogin, ugra and usñisin aspects. The northern head deviates from the text as well as from the Bhita sculpture in that it shows a shaven head and as such may be denoted as mundin. This head replaces 'the one that sports with Umā' of the epic, but again we are basically concerned with a differentiation of four aspects.

Attempts to explain these earliest Śaiva images according to a fivefold scheme should be considered as anachronistic (Bakker 1999). The linga or central figure itself was, when Śaiva theology developed, interpreted as the 'fifth' (invisible) aspect in order to bring the fourfold spatial arrangement into line with the non-iconographic fivefold division known from the Taittirīya Āranyaka (TS 1), which associates five mantras, i.e. five cosmic dimensions or functions with Sadāśiva; the first word of each mantra is explained by the commentator Sāyana as the name of a face (vaktra) of God (Parameśvara), viz. Sadyojāta, Vāmadeva, Aghora, Tatpuruṣa,

of the main figure to the southwest (nairṛti). According to the Gobhilagṛhyasūtra 4.7.41 a bali offering to the pitrs should be made to the southwest. Cf. Gonda 1980, $55 \mathrm{f}$. on 'the region of Nirrti (southwest), the awful goddess of decay'.

7 Kreisel 1986, 65; Abb. 57a-d. 
and $\bar{I}_{\text {śāna. }}{ }^{8}$ This synthesis of a spatial and a cosmological order postdates our earliest Śaiva sculptures; it is, to the best of my knowledge, for the first time presented in the Viṣnudharmottarapurāna 3.48.1-7 (TS 16). Consequently, there is in our view nothing remarkable ('auffallend') about the absence of the fivefold form of Śiva in the Mahābhārata as observed by Kreisel, since this form is equally absent in the early sculptures. ${ }^{9}$

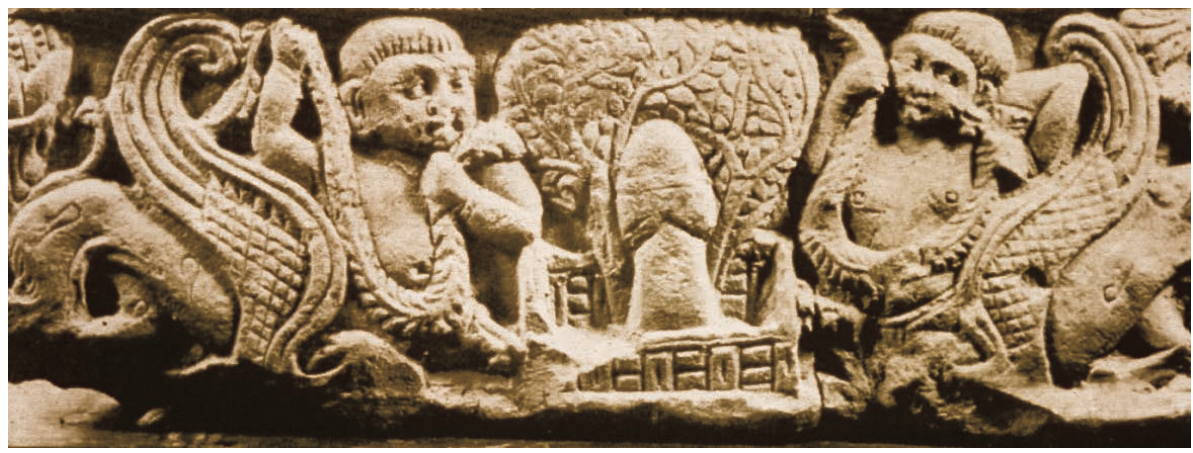

Plate 111

Mathurā: Architrave with scene of linga worship

What, on the other hand, is very remarkable is the comparatively little attention paid to the linga as a Śaiva cult object in our early Sanskrit texts. There is ample evidence which demonstrates that aniconic Śiva worship was widespread throughout the Indian continent at the beginning of the Common Era. Not only do we have, for instance, the testimony of the unequivocally phallic representation of Śiva from Gudimallam, ${ }^{10}$ which possibly dates from before the Common Era, but we also have an architrave from Mathurā, datable to the late Kṣatrapa period (middle of first century $\mathrm{AD}$ ), which shows a linga sanctuary (Plate 111). ${ }^{11}$ To this may be added the late-Kșatrapa Caturmukhalinga that we have just discussed and numerous lingas pertaining to the Kuṣāna period \&c. ${ }^{12}$

\section{Epigraphic sources attesting the worship of Śiva}

Due to this rich archaeological evidence of linga worship, some other data of the early period have also been interpreted as referring to Siva's linga, such as the

8 These five aspects, known in the scriptures of the Śaiva Siddhānta as 'the five Brahmans', are conceived of as being comprised in or as being the embodiment of Sadāśiva, an idea also reaching back to the Taittirīya Āraṇaka, which concludes the fifth formula of İ́āna with the words sadāśivom, glossed by Sāyaṇa as sa eva sadāsiva om.

9 Kreisel 1986, 21 n. 43: 'Auffallend ist jedoch, daß im Epos die Fünfgestalt Śivas fehlt.'

10 Kreisel 1986, Abb. A2a-b.

11 Kreisel 1986, Abb. 1a-c.

12 Kreisel 1986, Abb. 2-33. 


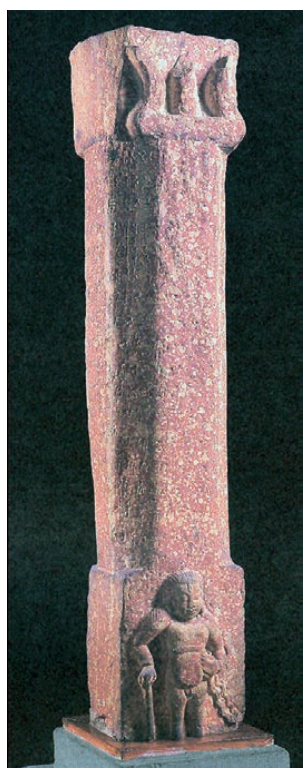

Plate 112

Mathurā: Pilaster

two cult objects mentioned in the Mathurā Pilaster Inscription of Candragupta II, Year 61 (AD 380/81), ${ }^{13}$ named Upamiteśvara and Kapileśvara, which were installed in a sanctuary dedicated to the Pāśupata masters in the guruparampara $\bar{a}$ of Kuśika (Plate 112). The latter may have been thought to be the pupil of Śiva's Kārohana avatāra, known as Lāguḍi or Lakulīśa from the fifth century onwards (above, p. 287). Probably on account of the ending 'iśvara', which later indeed mostly refers to a linga, these two objects are unanimously assumed to have been lingas, be it, according to D.R. Bhandarkar (followed by D.C. Sircar), lingas of a very peculiar type, viz. those that contain the "portraits of the teachers'. ${ }^{14}$ The text on the pillar reads (TS 12):

[...] āryoditāāāryena svapunyāpyāyananimittam gurūṇām ca kīrtyartham upamiteśvarakapileśvarau gurvāyatane guru ... pratișthāpito [|*] ${ }^{15}$

The illegible portion indicated by ... provides room for four, possibly five syllables of which the second seems to have been a ligature; Bhandarkar conjectured to read five: ${ }^{\circ}$ pratimāyutau, evidently conceived as an attributive adjunct of upamiteśvarakapileśvarau. To me this conjecture does not appear very plausible, for reasons of Sanskrit construction - one would expect the conjectured adjunct before and not after gurvāyatane. On the other hand, the position of guru ... directly before pratișthāpitau suggests an adverbial adjunct, saying that the installation was for the benefit/to the memory of the gurus or something like that. Moreover, to my knowledge, we do not possess archaeological evidence of lingas that are adorned with portraits of human teachers. Nor is Sircar's speculation to the effect that, 'the representations showed as if Upamita and Kapila were standing each with a Linga on the head', more plausible, in want of any archaeological basis. ${ }^{16}$ Apart from the names ending in ¿śvara, there is no evidence that the two objects installed were actually lingas.

That iconic images of Śiva were installed as main objects of worship in temples of this period may not only follow from the great number of early iconic images of Śiva (Maheśa) from Mathurā as described by Gerd Kreisel (Abb. 65126), it may be illustrated also by an image commissioned by a Māheśvara for a Śaiva temple in the first half of the fifth century, viz. the image installed by

13 Kreisel 1986, Abb. 126a-b. For the figure carrying a stick (Daṇdapāni) at the bottom see below, p. 558 and Plate 126.

14 Bhandarkar 1931-32, 5; cf. CII III (1981), 241; Sircar in SI I, 278 n. 5.

15 Sircar in SI I, 278; instead of ${ }^{\circ}$ sthāpito we should read ${ }^{\circ}$ șthāpitau.

16 Sircar SI I, 278 n. 5. 


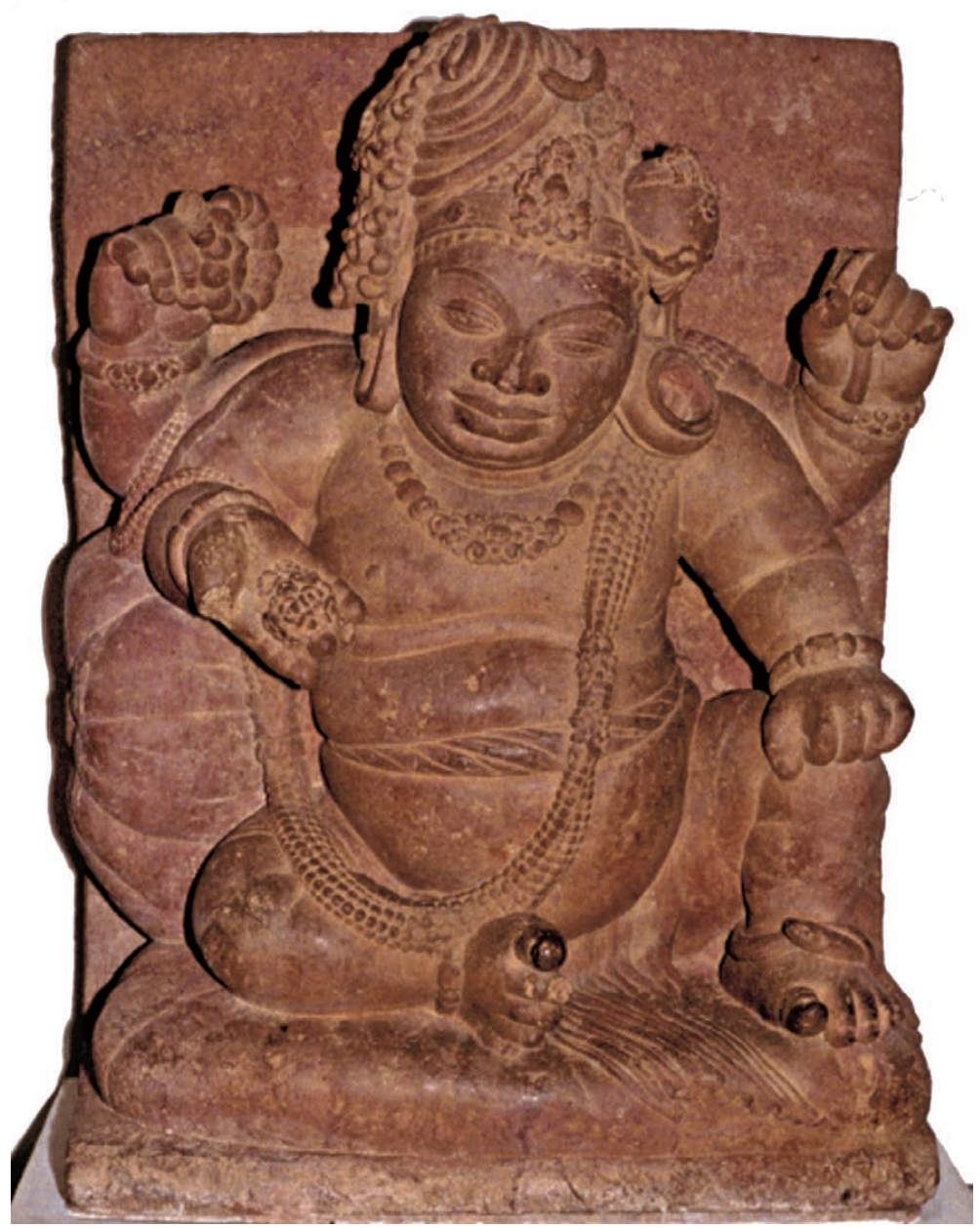

Plate 113

Mansar: Caturbhuja Śiva

Candragupta's grandson, the Vākātaka king Pravarasena II (Plate 113). This king refers to the deity in inscriptions as 'Pravareśvara'. ${ }^{17}$ As I have argued elsewhere, there are reasons to assume that this beautiful, four-armed Śiva image discovered on a hillock called the Hidimbā Ṭekd̄ī, $5 \mathrm{~km}$ due west of Ramtek Hill, in 1972, which to date embellishes the entrance hall of the National Museum in Delhi, represents this deity Pravareśvara. It may have been the main object

17 CII V, 19 1. 13: pravareśvara-șadviṃśakavātaka, and op.cit. 65 1. 1: pravareśvaradevakulasthāna. See also the sealing of Pravareśvara that came to light during the excavation of the Hiḍimbā Ṭeḳ̄̄ (MNS 3); above, pp. 373 f., Plate 75. 
of worship in the Vākāțaka state sanctuary (vaijayikadharmasthāna) named after the king 'Pravareśvaradevakulasthāna' (TS 13), which was situated on this hillock, near the present-day village of Mansar. ${ }^{18}$

Though in recent years a wealth of Śaiva sculptures have come to light pertaining to the eastern Vākātaka kingdom, no linga has been found among them. ${ }^{19}$ The Vākātaka kings were brahmins and the majority of them Māheśvaras, but their apparent reserve to patronize linga temples tallies with the Sanskrit texts of this period, in which linga worship is only reluctantly acknowledged.

\section{EARLY SANSKRIT SOURCES OF LINंGA WORSHIP}

\section{The Pāśupatasūtra and its commentary}

First of all, the authoritative text of the Pāśupata sect itself, the Sūtras and their commentary, do not mention linga worship with a single word. On the contrary, the commentator Kaundinya describes a manifestation of Śiva (mūrti) in iconic terms; his form (rūpa) is said to be characterized by the bull-banner etc.:

'Image' (mūrti): Either this (yad etad) form (rūpa) that is perceived by him who is standing at the right side of God, his face turned north, in (His) proximity, a form that is characterised by the bull-banner, the lance in hand, Nandin, Mahākāla, erect phallus etc., or to which ( yad vā) the laymen resort.

The sanctuary is 'of the Great God' (mahädevasya). This is the answer (iti). There is the object to be worshipped. ${ }^{20}$

\section{The Mahābhārata}

Though Rudra's phallic aspect is recognized in MBh 10.17.21, 12.160.46, and 13.17.74, there are only a few passages in the Mahābhārata where linga worship as such is acknowledged, the oldest of which may be the verses in Dronaparvan 172 and 173 (TS 3, 4 and 5), although these too are a matter of dispute. Discussing these passages Jacques Scheuer remarked,

Hopkins considère que la fin du Droṇaparvan est une addition tardive à ce livre. D'ailleurs, tout ce qui se réfère au lingga, écrit-il encore, n'appartient pas aux

18 Bakker 1997, 4 f., $87 \mathrm{f}$.

19 Excavations in Mansar after the writing of the present article have shown me wrong. Although I still think that the Mansar Siva image in the National Museum has been the main image of the temple complex unearthed at the Hidimbā Tekdịi, this complex contained at least six minor linga shrines. In the immediate surroundings of this complex also at least two other linga sanctuaries have been found. See Bakker 2004a and Bakker 2008.

20 Below, Textual Sources 10. This difficult passage deals with the concept of the Dakṣināmūrti. It is the vision of the initiated Pāśupata at the right side of the object of worship. This does not preclude that the latter itself is an aniconic representation of Śiva. This will be the subject of further discussion below, pp. $516 \mathrm{f}$. 
couches les plus anciennes de l'épopée. Dans une "critical note" de l'édition critique, S.K. De rejette la "conjecture" de Hopkins: le passage n'est pas si récent qu'il ne soit attesté par les principales familles de manuscrits. Cela est indéniable. A notre point de vue, cependant, il est plus intéressant de remarquer que le culte du linga ne semble jamais intervenir dans des passages se rattachant immédiatement au mythe central. Qu'il suffise ici de noter ce clivage. Il serait sans doute prématuré d'en proposer une explication. La mention du culte du linga est relativement claire. Les relations de Kṛṣna et de Rudra le sont moins. ${ }^{21}$

The Mahābhārata passages at issue run (TS 3 and 4):

Birth, karman, tapas, and yoga of these two (i.e. Nara and Nārāyaṇa) and of you (i.e. Aśvatthāman) are eminent; God has been adored by these two in the phallus (linga), by you in an image, during the various world-periods. He who adores the Lord in the linga, knowing Bhava to assume all forms, in him the disciplines concerning the self and the disciplines concerning learning are everlasting. For the gods and Siddhas and great seers, by worshipping in this way, strife to attain the highest in the world and the everlasting station. And this very Keśava (Kṛṣna) is a votary of Rudra, being born from Rudra; this Kṛ̣na who is eternal is also to be worshipped with sacrifices. He who adores the Lord in the phallus, knowing Him to exist in all creatures, in him the One whose emblem is the bull (i.e. Śiva) takes an extraordinary delight.

Because his phallus stands erect in perpetual celibacy and the people worship greatly (mahayanti), (therefore) is he known as the Great Lord (Maheśvara). Seers, gods, Gandharvas and Apsarases also have adored his phallus, and that one also stood erect. Therefore that Great Lord (Maheśvara) rejoices when his (phallus) is worshipped; Śamkara becomes happy and gratified and he is delighted.

The latter text is with some minor variants found again in Anuśāsanaparvan 146.15-18 (TS 8), which may indicate that the Dronaparvan passage belongs to an older stratum of the epic. An explicatory śloka, which is also found in the Dronaparvan but in another context (MBh 7.173.94; TS 5), and which seems to echo MBh 7.172.87 and 90 (TS 3), has been inserted (MBh 13.146.16), somewhat disturbing the syntax, since the relative pronoun yo in 16a lacks a clear antecedent. ${ }^{22}$ This verse unequivocally refers to the linga as a particular cult object distinct from an iconic image (vigraha). It says (TS 8 v. 16), ${ }^{23}$

One who worships the body (i.e. image) of the magnanimous one (i.e. Śiva), or otherwise his phallus (linga) - the constant worshipper of the phallus shall obtain great prosperity.

The fourth, or, if we count the Dronaparvan passage and its reprise in the Anuśāsanaparvan as one, third passage advocating linga worship is also found

21 Scheuer 1982, 277.

22 This also holds true for MBh 7.173.94.

23 Cf. the Gṛhyapariśiștasūtras of Baudhāyana (3rd-4th centuries AD?), which say that if Siva is worshipped in an image there is an eye-opening rite, when in a linga there is not (TS 11). Cf. ibid. II.17 (Harting 1922, 10 1. 23). 
in book thirteen. On the question of Śakra why he does not wish prasā da from anybody but Śiva, Upamanyu answers (TS 6 vv. 100-102),

What other reasons do you need, the Lord is the primary cause. It has not been revealed to us that the gods adore the phallus (linga) of anybody else; of whom else than Maheśvara is the phallus worshipped by all gods, or has ever been worshipped? Tell me if it has been revealed to you. Whose phallus Brahmā, Viṣnu and you too with the gods should always adore, that one is the chiefest for that reason.

\section{The Rāmāyana}

The Rāmāyaṇa confirms the impression obtained from the Mahābhārata: though a later tradition ascribes to Rāma the foundation of the Rāmeśvara linga, this is not found in the critical edition of the Ādikāvya itself. ${ }^{24}$ Linga worship is only ascribed to the Rākṣasas led by Rāvaṇa (TS 9), who worships with incense and fragrant flowers a golden linga, which he had installed on an altar of sand on the bank of the Narmadā River. 'And after the worship he sung and danced, waving and spreading his hands' (TS 9 v.40). It may be significant that in the Mahābhārata passages great emphasis is laid on the fact that gods and other divine beings also worship Śiva's linga, ${ }^{25}$ which sounds like a sort of justification, whereas the Rāmāyaṇa confines linga worship to Rākṣasas in a tone of scarcely concealed dismay.

\section{ConCluding observations}

The overall impression that we may gather from the material surveyed is that, during the first centuries of the Common Era, the brahmanical elite, whether priest, king or renouncer, preferred to venerate Maheśvara in iconic form and frowned upon linga worship. ${ }^{26}$ Its gradual acceptance in the 5 th and 6th centuries by those circles that earlier rejected it may be illustrated again by the myth of Tilottamā.

\section{The evidence of the Skandapurāna}

This myth recurs in what we think is the original Skandapurāna, which we date in the sixth or seventh century, and which may have been composed in Pāśupata circles. ${ }^{27}$ Here explicit reference is made to Śiva in his linga form (TS 14): 'There arose amidst these celestials a linga, solid, massive, a bundle of tejas as it were.' From this linga four faces emerged when Tilottamā made her circumambulation, the eastern one lustrous, with lips gracious as the bimba

24 Eck 1991, $62 \mathrm{f}$.

25 MBh 7.172.88; 7.173.84; 13.14.101 f.; 13.146.17.

26 Gonda 1960, 256: 'Möglicherweise ist dieser Phallus ursprünglich nicht mit dem Śivadienst verbunden gewesen, wie denn auch gebildete Kreise öfters Bedenken gegen dessen Verehrung getragen haben.'

27 See Bakker \& Adriaensen \& Isaacson 1994. Bakker 2014. Above, pp. 185 ff., p. 469. 
fruit (prasannabimbauștha) and with three eyes (tryaksa) (TS 15 vv. 16-17); the southern one "possessed of the colour of a languid cloud laden with water, having a ferocious voice, with dreadful teeth shining (in an open mouth), and the corners of the eyes bloodshot and glittering' (v.19); the western face was perfect (anuttama) having three eyes, and the northern one was very full (susampūrna) and very gracious (suprasanna) (vv.21-24). Thus runs the oldest description of the Caturmukhalinga in the Sanskrit literature known to me, at least half a millennium after the Indian sculptors had begun to materialize the idea in stone (see also below, p. 521).

\section{Conclusions}

The various sources surveyed above lead to the following conclusions.

1 The historic reality of ancient Siva worship, which is taken here as a specimen of a wider issue, cannot be reconstructed by relying on one type of source only. If we would base ourselves on texts alone, we would hardly be aware that linga worship was practised on a large scale throughout the Subcontinent during the first centuries of the Common Era. If, on the other hand, we would not have texts, we would be at a loss how to interprete the phallic stones provided with four heads of different countenances.

2 When the visual material is interpreted with the help of written sources it is of paramount importance that both sources date from about the same time. More often than not art-historians describe their visual material on the basis of textual material that dates from half a millennium later, such as when early sculptures are explained by having recourse to the iconographic treatise of the Viṣnudharmottarapurāna or still later texts, while, as we have seen, contemporaneous descriptions are sometimes to be found in, for instance, the Mahābhārata.

3 The incongruity that is frequently found between the archaeological material and textual descriptions may have its root in the different sections of the society to which these sources pertain. This makes us realize how tentative our assessments are and how little we actually know about the early history of the religions of India.

4 If these three conclusions are accepted it follows finally that, in view of the scarcity of sources at our disposal, we simply cannot afford to disregard any of them. When, however, we evaluate them and try to construe an integral picture of the past, we should never lose sight of their innate differences and we must proceed with the utmost caution, in the knowledge that the complexity of the historic reality of ancient India is far greater than we can ever hope to recover. 


\section{Textual sources (TS)}

1 Taittirīya Āranyaka 10.43-47

sadyojātam prapadyāmi sadyojātāya vai namah $\mid$

bhave bhave nātibhave bhajasva mām | bhavodbhavāya namah $\| 43$ ॥ vāmadevāya namo jyeșthāya namah śreșthāya namo rudrāya namah kālāya namah kalavikarañāya namo balavikarañāya namo balapramathanāya namah sarvabhūtadamanāya namo manonmanāya namah $\|44\|$ aghorebhyo 'tha ghorebhyo ghoraghoratarebhyah | sarvatah śarva sarvebhyo namas te astu rudrarūpebhyah \| 45 \| tatpurușāya vidmahe mahādevāya dhìmahi|

tan no rudrah pracodayāt $\| 46$ \|

īśānah sarvavidyānām ̄̇śvarah sarvabhūtānām brahmādhipatir brahmaṇo 'dhipatir brahmā śivo me astu sadāśivom || 47 ||

2 Mahābhārata 1.203.21-26

prānmukho bhagavān āste dakșiṇena maheśvarah devāś caivottarenāsan sarvatas tv r ̣sayo 'bhavan $\|21\|$ kurvantyā tu tayā tatra mandalam tatpradakșinam| indrah sthānuś ca bhagavān dhairyena pratyavasthitau \| 22 || draștukāmasya cātyartham gatāyāh pārśvatas tadā| anyad añcitapakșmāntam dakșiṇam nihṣtam mukham || 23 || prsțhatah parivartantyāh paścimam niḥstạtam mukham| gatāyāś cottaram pārśvam uttaram nihsṣtam mukham || 24 || mahendrasyāpi netrānām pārśvatah prșthato 'gratah raktāntānām viśālānām sahasram sarvato 'bhavat || 25 || evam caturmukhah sthānur mahādevo 'bhavat purā tathā sahasranetraś ca babhūva balasūdanah \| $26 \|$

3 Mahābhārata 7.172.86-90

janmakarmatapoyogās tayos tava ca puskalāh $\mid$ tābhyām linge 'rcito devas tvayārcāyām yuge yuge \| $86 \|$ sarvarūpam bhavam jñātvā linge yo 'rcayati prabhum| ātmayogāśs ca tasmin vai śāstrayogāś ca śāśvatāh || 87 || evam devā yajanto hi siddhāś ca paramarsayah| prārthayanti param loke sthānam eva ca śāśvatam || 88 || sa esa rudrabhaktaś ca keśavo rudrasambhavah krșna eva hi yaștavyo yajñaiś caișa sanātanaḥ $\|$ 89 || sarvabhūtabhavam jñatvā linge 'rcayati yah prabhum| tasminn abhyadhikām prītim karoti vrṣabhadhvajah || 90 \| 


\section{Mahābhārata 7.173.83-85}

nityena brahmacaryena lingam asya yad āsthitam*|

mahayanti ca lokāśs ca maheśvara iti smrtah || $83 \|$

rsayaś caiva devāś ca gandharvāpsarasas tathā|

lingam asyārcayanti sma tac cāpy ūrdhvam samāsthitam || 84 \|

pūjyamāne tatas tasmin modate sa maheśvarah $\mid$

sukh̄̄ prītaś ca bhavati prahrștaś caiva śaṃkaraḥ\| 85 ||

* The edition reads yada sthitam.

\section{Mahābhārata 7.173.92-94}

dahaty ürdhvam sthito yac ca prānotpattisthitas* ${ }^{*}$ ca yat

sthitalingaś ca yan nityam tasmāt sthānur iti smṛtah \| 92 \|

visamasthah śarīresu samaś ca prāninām iha|

sa vāyur vișamastheșu prānāpānaśarīrișu $\mid{ }^{*} 3 \|^{* *}$

pūjayed vigraham yas tu lingam vāpi samarcayet|

lingam pūjayitā nityam mahatịn śriyam aśnute $\| 94$ ||***

* The editors of the Anuśāsanaparvan, where the same verse is found (MBh 13.146.10), opted for another reading: prānotpattih sthitiś. ** MBh 13.146.20 has an important variant reading: vișamasthah śarīreșu sa mṛtyuh prāṇinām iha| sa ca vāyuh śarīreșu prāṇo 'pānah śarìrinām $\| 20$ || *** Cf. MBh 13.146.16 (TS 8 v. 16).

6 Mahābhārata 13.14.99-102

śakra uvāca|

kah punas tava hetur vai isé kāranakāraṇe|

yena devād rte 'nyasmāt prasādam nābhikāinkșasi || 99 ||

upamanyur uvācal

hetubhir vā kim anyais te $\bar{\imath}$ śh kāraṇakāraṇam|

na śuśruma yad anyasya lingam abhyarcyate suraih || 100 ||

kasyānyasya suraih sarvair lingam muktvā maheśvaram|

arcyate 'rcitapūrvam vā brūhi yady asti te śrutih || 101 ||

yasya brahmā ca viṣnuś ca tvam cāpi saha daivataih|

arcayadhvam sad̄̄ lingam tasmāc chreșthatamo hi sah\| 102 \|

7 Mahābhārata 13.128.3-8

yato yatah sā sudatī mām upādhāvad antike|

tatas tato mukham cāru mama devi vinirgatam $\|3\|$

tām didṛkșur aham yogāc caturmūrtitvam āgatah $\mid$

caturmukhaś ca saṃvṛtto darśayan yogam ātmanah $\|4\|$

pūrvena vadanenāham indratvam anuśāsmi ha|

uttareṇa tvayā sārdham ramāmy aham anindite $\|5\|$

paścimam me mukham saumyam sarvaprāṇisukhāvaham|

dakșinam bhīmasamkāśam raudram saṃharati prajāh $\|6\|$

jatilo brahmacārī ca lokānām hitakāmyayā|

devakāryārthasiddhyartham pinākam me kare sthitam \| 7 \| 
indreṇa ca purā vajram kṣiptam śrīkāìkșiṇa mama| dagdhvā kantham tu tad yātam tena śrìkaṇthatā mama \| 8 ||

8 Mahābhārata 13.146.15-18

nityena brahmacaryena lingam asya yad āsthitam| mahayanty asya lokāśs ca maheśvara iti smṛtah || 15 \| vigraham pūjayed yo vai lingam vāpi mahātmanah| lingam pūjayitā nityam mahatīṇ śriyam aśnute || 16 || rṣayaś cāpi devāś ca gandharvāpsarasas tathā| lingam evārcayanti sma yat tad ūrdhvam samāsthitam \| 17 \| pūjyamāne tatas tasmin modate sa maheśvarah $\mid$ sukham dadāti prītātmā bhaktānām bhaktavatsalah $\| 18$ ||

\section{Rāmāyaṇa 7.31.38-40}

rāvaṇaṃ prāñjaliṃ yāntam anvayuh sapta rākșasāh $\mid$

yatra yatra sa yāti sma rāvano rākșasādhipaḥ| jāmbūnadamayam lingam tatra tatra sma n⿳亠丷⿵ate || 38 ||

bālukāvedimadhye tu tal lingam sthāpya rāvanah $\mid$ arcayāmāsa gandhaiś ca puṣpaiś cāmrtagandhibhih || 39 || tatah satām ārtiharam haram param, varapradam candramayūkhabhūṣaṇam| samarcayitvā sa niśācaro jagau, prasārya hastān prạ̣anarta cāyatān $\| 40$ \|

10 Kauṇdinya ad Pāśupatasūtra 1.9 (Sastri's ed. p. 15)

mūrtir nāma yad etad devasya dakșiṇe pārśve sthitenodarimukhenopānte yad rūpam upalabhyate| vrșadhvajaśūlapāninandimahākālordhvalingā̄dilakșanam| yad vā laukikāh pratipadyante| mahādevasyāyatanam iti $\mid$ tatropastheyam |

11 Gṛhyapariśiștasūtras of Baudhāyana II.16 (Harting 1922, 7 ll. 16 f.)

hiranyena tejasā cakṣur vimocayet tejo 'sīti

linge cen nivartate cakșuṣor abhāvād|

12 Mathurā Pilaster Inscription of Candragupta II, Year 61 (Sircar SI I, 278 1l. 5-10; cf. CII III (1981), 240)

asyām pūrvvāa[yām] [bha]gava[tku]śikād daśamena bhagavatparāśarāac caturthena [bhagavatka*]pi[la]vimalaśișyaśișyena bhagava[dupamita*]vimalaśișyena $\quad \bar{a}$ ryyodi $\left[\operatorname{ta}^{*}\right]$ cāryye $\left[n a^{*}\right] \quad[$ sva* $] p u[n y \bar{a}]$ pyāyananimittam gurūṇạm ca kīrtya[rtham upamiteśva] rakapileśvarau gurvvāyatane guru ... pratișthāpito [read: ${ }^{\circ}$ tau] $\left(\left.\right|^{*}\right)$

Bhandarkar conjectures gurupratimāyutau for guru ... 
13 Pāṇḍhurṇā Plates of Pravarasena II (CII V, 65 ll. 1 \& 34-36)

drștam | pravareśvaradevakulasthānāt $\mid \quad[\ldots]$

viditam astu vo yathehāsmābhir dharmāyurbalavijayavivṛdhaye ihāmutra hitārtham ātmānugrahāya vaijayike dharmasthāne apūrvadattyā udakapūrvam atisrsțtah|

Readings corrected with the help of other similar inscriptions. Mirashi notes that we should read atisrșța, 'if it has to qualify some word like bhümih'.

14 Skandapurāṇa 62.12 (SP III, 260)

atha lingam samuttasthau teșām madhye divaukasām | susaṃhatam susaṃśliștam samūhas tejasām iva\| 12 \|

15 Skandapurāṇa 62.16-24 (SP III, $261 \mathrm{f}$ )

neme mūrtim tad̄̄ pūrvām nihsasāra tato mukham| tryakṣam prasannabimbauștham amitadyutikāntimat || 16 ||

atha tejo vinihsrtya vadanendoh pinākinah $\mid$

tām viveśāinganām āśu śaradbhāskarabhāsvaram \| 17 \|

atha sā daksin̄ām mūrtim praneme cārudarśanā|

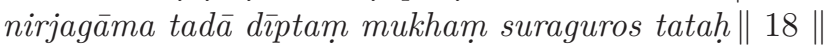

vāribhārālasāmbhodarucimad bhīmanisvanam|

karāladaśanodbhāsi dīptaraktāntalocanam || 19 ||

atyādityam tatas tejo mukhān nihsṣtya daksināt|

dŕśyamānam suraih sarvair viveśa pramadottamām $\| 20$ ||

praneme sā tatas tasya paścimām mūrtim añjas $\bar{a} \mid$

niścakrāma tatas tasyā mukham tryakșam anuttamam || 21 \|

tatas tejo vinihsrtya mukhendor madanadvisah

dīpyamānam viveśāśu tām eva pramadottamām $\| 22$ \|

uttarām mūrtim āgamya praneme sā krtā̃njalih |

tasyā mukham susaṃpūrnam suprasannam viniryayau\| 23 \|

tasmāt tejo vinihsṛtya sūryadīptānalaprabham|

viveśa pramadām āśu tām eva varavarṇin̄̄m \| $24 \|$

16 Vị̣nudharmottarapurāṇa 3.48.1-7

sadyojātam vāmadevam aghoram ca mahābhuja|

tathā tatpuruṣam jñeyam issānam pañcamam mukham \| 1 \|

sadyojātam mah̄̄ proktā vāmadevam tath $\bar{a}$ jalam |

tejas tv aghoram vikhyātam vāyus tatpuruṣam matam|

iśānam ca tathākāśam ūrdhvastham pañcamam mukham \| 2 \|

vibhāgenātha vakṣāmi śambhor vadanapañcakam|

mahādevamukham jñeyam pūrvam śambhor mahātmanah $\mid$

netrāṇi trīni tasyāhuh somasūryahutāśanāh \| $3 \|$

dakșinam tu mukham raudram bhairavam tat prakīrtitam| paścimam yan mukham tasya nandivaktram tad ucyate $\|4\|$

umāvaktram ca vijñeyam tasya devasya cottaram| 
sadāśivākhyam vijñeyam pāvanam tasya pañcamam| trilocanāni sarvāṇi vāmadevam dvilocanam \| 5 \| mahādevamukham bhūmis* tejah syād bhairavam mukham | nandivaktram tath $\bar{a}$ vāyur* aumeyam cāpa ucyate| sadāśivākhyam vijñeyam ākāśam yadunandana \| 6 \| diśo daśa bhujās tasya taddvayam ** vadanam prati mahādevakare jñeyāv akșamālākamaṇdalü\| 7 \|

Text as given in Shah's edition; śloka numbering mine. * It might be argued that bhümis and vāyur have been interchanged. ** I follow the MSS A and B of Shah's edition; this editor opted for the unintelligible vijñeyam. 